\title{
Numerical analyzation by airphotos for forestry purpose
}

\author{
by Iwao Nakajima \\ Government Forest Experiment Station. \\ Cheaf of the Photogrammetry Laboratory.
}

\begin{abstract}
Resume
It has the necessity to clearly find out the relationship among the many forest composition factors, such as forest conditions, growing surrounderings or artificial infuluenses for getting acculate informations of the present and futur state on forest.

Surely, the useful application of air photo informations with numerical analyzation by electric computor on aboved purposes shall brought the effective development of the sientific forest survey method.

On these purposes, the observation eye field must be clanged from limited necked eye base to variable photo eye's, both are quite different each other.

When we use the air photos as the agency of the actual forest, the factors of the observations composed by forest composition figures from higher position and conditions of their surrounderings.

We can catch many useful informations from this wider eye field on active forest conditions.

In this report, auther discuss the principle and actual method of the estimation on forestry purpose such as stand volume, growth or inferior volume by useing these photo observation factors with multifactor analyzation method, with referencing some results of numerical analysis on natural and artificial forest of Japan.

These method must be read out the higher advancement of the systematic application of photo interpretation in more wider use.
\end{abstract}

はじめに 森林の現況と推移を予測するには, 林木 自体や生育する環境，人為条件などの多くの関連する 要因を解明する必要がある。空中写真の持つ豊富な情 報を利用し，数量解析の手法をそれに導入すること は, 調査の能率と科学性を高めるために明らかに有効 な万法である。そのためには従来肉眼観祭を基準とし て行なわていた森林の测定を, 肉眼とは全く異なる視 野に立った空中写真の視野での観察要因に置さかえね ばならない, 写真像を中介としたとき, 森林観察の要 因は上空より見た森林の構造とそれをとりまく環境立 地の状態である。

この観察要因が森林構造のなかで，どの様に相互に 関連し, また現在森林計画立案に要求される材積量, 生長量, 枯損量等の推定にどのように関与するかを多 変量解析によって求め, またそれらから上記のものを 所要の精度をもって推定するための数值表の作成につ
いて，国有林に和ける天然林，人工林について実施し ている研究例を参考に原理と手法を報告する。この様 な手法はステレオグラムおよび写真像の科学的利用, 京た写真情報解析システムの開発えの足脚りを提供す るものであうう。

\section{1. 写真情報利用の原則}

Principle for Photo information usages.

森林は, 生育する個々の立木が集合して形成する一 つの生物社会である。林木は互に密接な関連を保ちな がら，それらを取り巻く環境との有機的な結びつきの 中に盛衰を繰り返している。

過去より現在に至るまで, 森林は木材生産の場とし て開発され管理されて来ているが，近代社会の高度な 経済発展は, 而に同じく生物体である人間社会の生活 環境の調和と保全に対する機能をも森林の上に要求し てきている。

元来, 森林は, 鉱物資源などとは異なり, 現在から 
将来につながる再生産性を重視すると共に, 自然と人 為の操作とが刻々と変動を与える動的な現象として, 一時点の状態, 推移の原因や過程, 社会経済の中での 生産価值等が求められる情報と, それに基いた計画的 な経営と利用が扣こなわれる必要がある。

森林は昔から人間の肉眼による観察と, 頭脳による 判断の尺度に上って評価さ记計画が立てられてきた。 それはいわば「山にある木を人が使う」立場からの資 源量の面を主体とした考察であって, 静止した森林の 一断面をとらえる努力であるといえる。

これを有機的な生物集団として動的に見ようとすれ ば, 従来の人間の肉体的, また頭脳的な能力限界を, さらに拡張したより広い視野と判断力が必要となる。

それは肉眼で見られるよりもより小さな空間と同時 に，より大きな空間，すなわち「目的物を取りまく外 界々の有機的な関連を追求させる空間」の系統的な観 察と綜合的な判断能力の要求である。

いわげ空間を縮少, 拡大し, 時間を延長し短縮もす る目が，そしてその目には科学的な説得力をもつ客観 的表現を可能にする手だてがな计机ばならない。

写真は人間の観察目の縮尺を自在に選び得ることを 可能とした。また写真を仲介とすることによって写さ れた被写体のすべては数值測定の手法えと持込まれら れるに至った。

従来上り空中写真は林業の分野においても基本図や 林型区分図の作成基他, 多くの効果をあげてきてい る。だがそれは従来の肉眼の補助としての利用に止ま っている。今日の写真の有する効果をより上く活用す る為にはその豊富な情報を順序上く取り出すと共に, それらの関連をとき調查目的に向って編集する情報解 析システムの適切な活用が期待されなければならな い。それによってょうやく人間の観察力と判断力は增 大するといえる。

\section{2. 森林における写真観察の要因}

Items of Photo Observation for forestry use.

森林経営にとって従来より最も基本的に要求されて きたものはそれぞれの時点に打ける立木材積, 生長量 また枯損等の情報である。それに基づいて撫育や伐採 の計画が立てられ評価が括こなわれてきた。これらは 社会的な森标の見方の推移いかんにかかわらず重要な ものである。森林の現況のこれらの情報と, 条件によ って変化するであろう予測の值がえられるとき, 始め て具体的な計画を立てら机る。

これらは従来, 地上調査によって求められていた。 刘象地域が広大な場合には主に標本調査法が用いら れ, 空中写真はこのとき調査準備の林型区分図や現地
調查点えの誘導, 確認等に用いられ前記各主目的情報 のデータは地上測定による標準地の立木の樹高, 直 径, 本数, 年輪巾等々が用いられた。

今, 写真像の観察を主体として前記の各情報を求め 上うとすれば, 調査測定の要因はこのような肉眼観察 法に準拠するものとは多くの異なったものが主体とな ってくるはずである。それは写真条件によっても暴な るものではあるが, 根本的には視界とする空間の相異 である。そこでは個々の立木の值よりも, それらの相 互の関係や, 森林としての総体的な值, 宗九生育地域 の地形, 環境が有力な観察要因である。地上調査でも 森林測定の票因は情報を引き出す為の一次要素である のが常であるとき, 従来しばしば武みられたことこは あるが写真利用でそれと同じ測定要因の推定に努力す ることは不得策であろう。

空中写真像として森林が記録されているものは上空 上り見た森林の構造と生育地の状態であることからは こ礼らから直接目的とする情報を引き出す関連を求め ることが写真利用を効果的にしうるものである。

写真に上り森林を整理分類する要因については, 従 来より林型区分を対象として行なわれてき心が，更に そ礼を有機的に見上うとする時には多くの人為と自然 による立地条件の要因が加わる。

これらのうち社会経済的なものを除いて森林自体と 自然条件のみを取り上げた場合, 写真上の観察要因は Table 1 の票因 (Item) の如くになろう。同じくそ の Table に拈いての区分 (Category) は1/20,000 空 中写真によって北海道天然林の調查を対象として栲察 しな場合の例である。このような区分は写真観測によ って何等高度な機械や技術を用いず，全く基礎的学技 術で扰こなわれることができ且つ判定の誤りがもっと も少なくてすむような粗さを考慮したものである。第 1.の樹種群から4.の径級構成までは天然林に扣いて特 に複雑に出現するものであり，樹種群は地域によって 刘象とする主林木は異なる。なお樹冠直径又は樹冠面 積は写真上上層木については測定可能であるが, 一斉 林形, 或いわ熱带林地方等の如く上層木が比較的约一 な状態によるときは適正な要因であり，測定の難易さ 恚考えて, また他の要因との相関を検討した上で採用 一べきである。要因5.〜7. 本では, 従来の林型区分基 準と同じで女る。8.0疎密度形は特に森林被害や表土 荒廃に関連して明らかな表机方をとる。

9.〜13.はいら゙れも林木の生長に直接間接に影響を 多つ立地条件であり, 微気象, 降水量, 土性等もこ礼 らと密接な関連をもつ，14. の地床は主に天然の林木 更新造林撫育に大きな関連をるつが多くの場合に問題 之なるのはササの被覆である。樹冠で地上が完全にお 


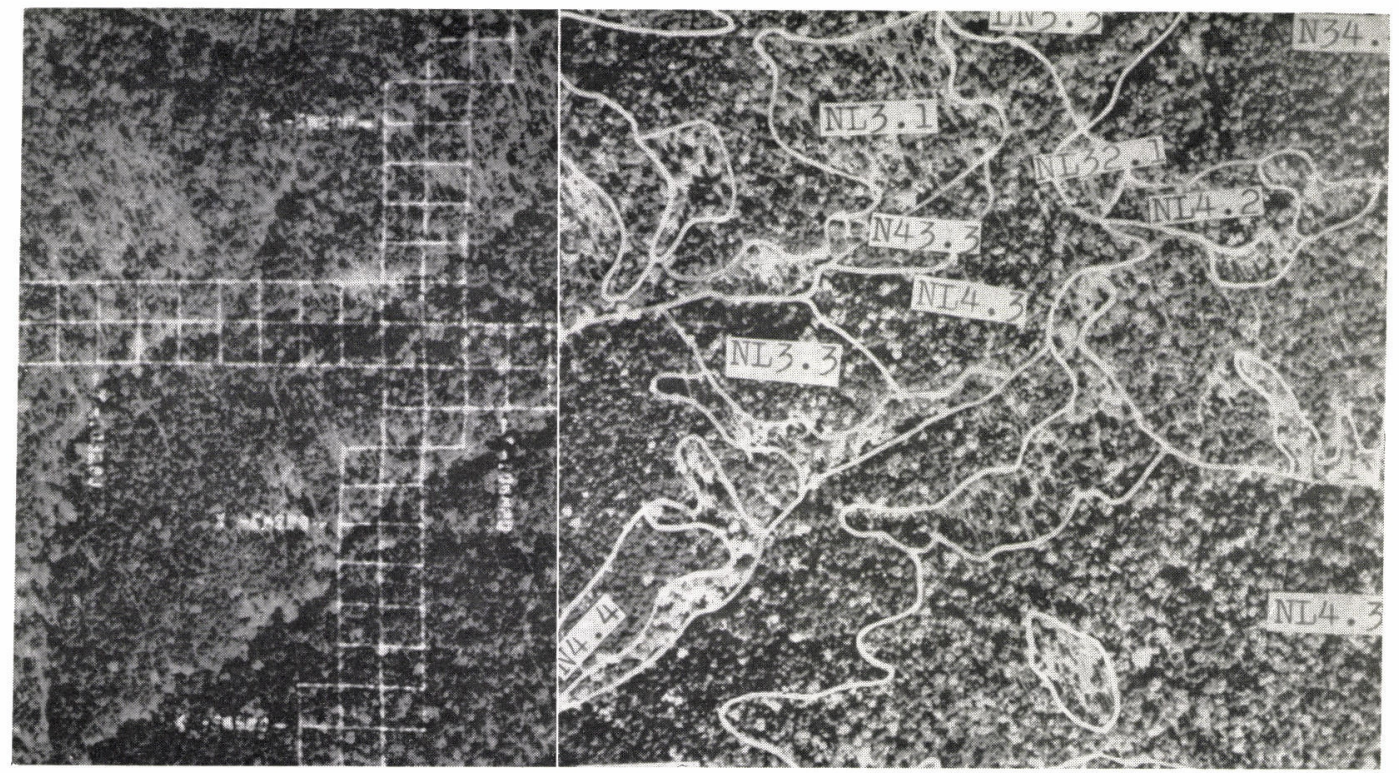

北海道トムラウシ天然林 林型区分写真

Type classification on Tomuraushi Natural Forest.

Original scale 1/20,000. 28th. Sept. 1967. Stereo-meshe 40 X $40 \mathrm{~m}$.

拈われた場合は, 赤外カラー写真でもその局地の地床

判定は不能であるのでこの要因は推定しうる場合に限

られよう。

\section{3. 写真情報の解析}

Numerical Analization of Photo Information.

これらの要因が標本地資料や系統的に編集されたス

Table 1 Items and Category for Forest Type Classification of Natural Forest in Hokkaido 写真林型区分要因 (北海道天然林判読基準)

photo scale $1 / 2,000$

\begin{tabular}{|c|c|c|c|}
\hline & 嬖因 (Item) & 分 (Category) & \\
\hline 1 & 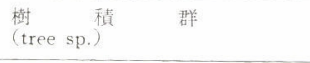 & $N_{x} y, N_{ト} ト r, N_{x}, N L, L$ & {$[5]$} \\
\hline 2 & $(\operatorname{mix} \%)$ 绪 全 & $\mathrm{N}, \mathrm{N}>\mathrm{L}, \mathrm{N} / \mathrm{L}, \mathrm{LN}, \mathrm{L}$ & {$[5]$} \\
\hline 3 & $\begin{array}{l}\text { 混 } \\
(\operatorname{mix} \text { type })\end{array}$ & 均等 $(\mathrm{U})$ ，塊状 $(\mathrm{G})$, 団状 (H) & {$[3]$} \\
\hline 4 & $\begin{array}{l}\text { 径 級 榑 成 } \\
\text { (mix Type Composition) }\end{array}$ & 小径木 $(\mathrm{Y})$ ，中径木 $(\mathrm{B})$ ，大径木 $(\mathrm{O})$ およびをの組合せ & {$[9]$} \\
\hline 5 & $\begin{array}{l}\text { 上層木平均樹高階 } \\
\text { (Av. Hight of Dominant T.) }\end{array}$ & $\sim 10 \mathrm{~m}\left(\mathrm{H}_{1}\right), \quad 11 \sim 18\left(\mathrm{H}_{2}\right), \quad 19 \sim 25\left(\mathrm{H}_{3}\right)$ & [4] \\
\hline 5 & 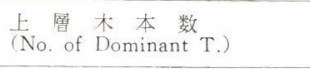 & 小 (few), 中 (med), 大 (many) & {$[3]$} \\
\hline 7 & $\begin{array}{l}\text { 樹 冠 踈 密 度 } \\
\text { (Crown Density) }\end{array}$ & 散 $(\mathrm{Vo})$, 㻋 $(\mathrm{O})$, 中 $(\mathrm{M})$, 密 $(\mathrm{D})$ & {$[4]$} \\
\hline 8 & $\begin{array}{l}\text { 疎 度: } \\
\text { (Density } \\
\text { Type) }\end{array}$ & 均等 $(U)$, 群状 $(G)$, 団状 $(H)$ & {$[3]$} \\
\hline 9 & (Altitude) & $0 \sim 99, \quad 100 \sim 199, \quad 200 \sim 299, \quad 300 \sim$ & {$[4]$} \\
\hline 10 & 方 (Azimuth) 位 & $0, N, N E, E, S E, S, S W, W, N W$ & [9] \\
\hline 11 & (Tilt) 倾 & $0 \sim 9^{\circ}, \quad 10 \sim 19^{\circ}, \quad 20 \sim 29^{\circ}, 30 \sim$ & [4] \\
\hline 12 & $\begin{array}{l}\text { 地 } \\
\text { (Land type) }\end{array}$ & 山頂 (Top), 台地 (Terres), 平衡 (Smoth), 凹, 凹, 浸蝕 (Elodid), 推積 (Piled) & {$[7]$} \\
\hline 13 & (Position) 位 & 尾根 (Ridge), 中腹(上) (Side U), 中腹(下) (Side L), 沢 (Botum) & [4] \\
\hline \multirow[t]{2}{*}{14} & (Ground flora) 㕅 & ササ（Sasa），雑灌（Bush），無（Non） & {$[3]$} \\
\hline & & Total & {$[67]$} \\
\hline
\end{tabular}


テレオグラムによって求められれば，とれは各要因間 の相互の関連性と，各種の推定目的に対してそれらが ぞの様な重要さで関与しているかを多変量解析の手法 を応用して求めることができる。それは推定すべき目
的の基準值に対して，夫々の要因（Item）の各区分 (Category) を変数とし，推定の誤差を最小にするよ らな多次元の連立方程式を解くことである。

この場合，外的基準と呼ばれる推定目的の基準値は

Table 2 Ordering and Partial-Correlation Coefficient of Photo-Observation Factors for Some Estimation on Natural Forest in Hokkaido

写真判読要困の推定に関与する順位之偏相関

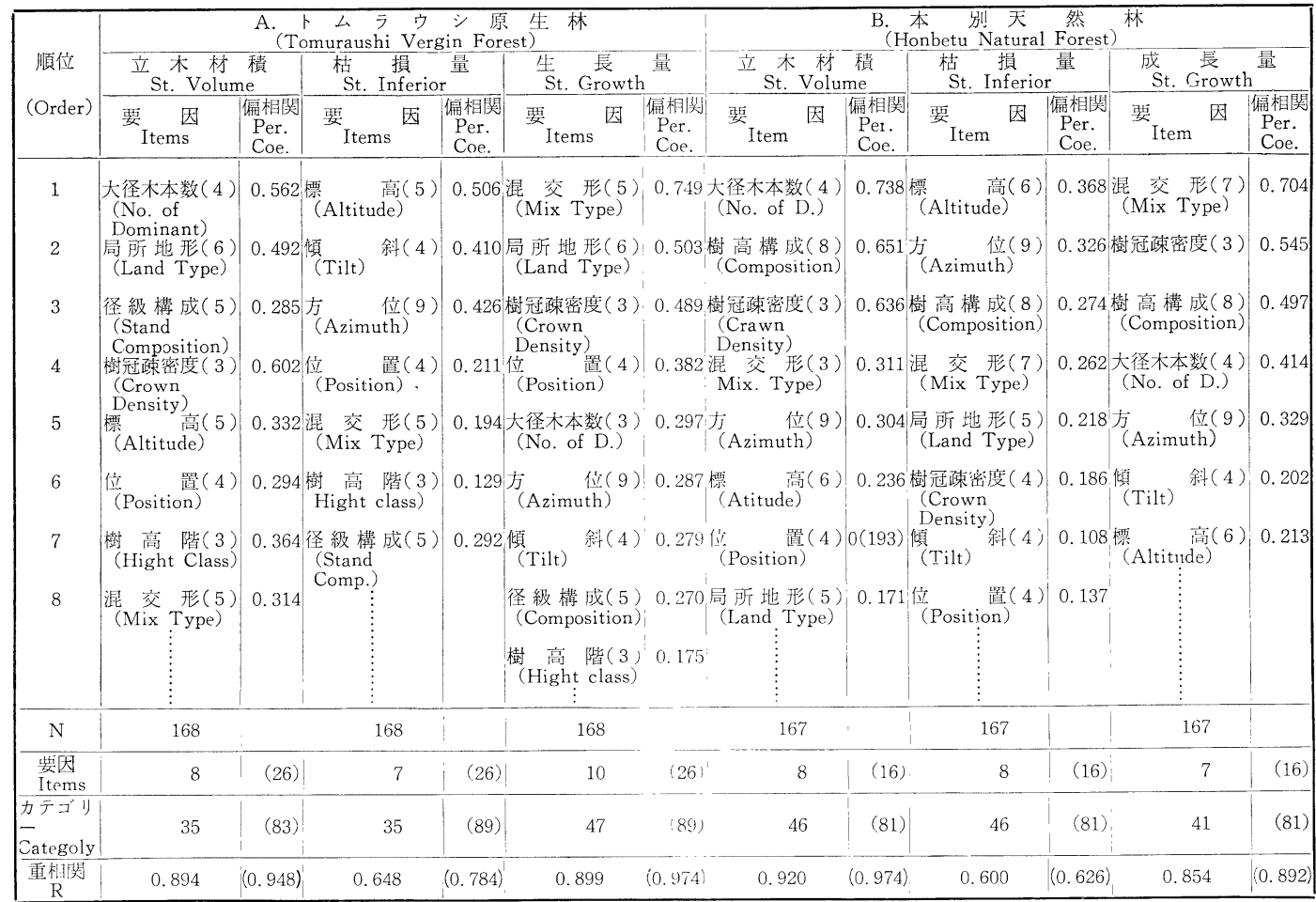

Table 3 Multi and Pertical correlation Coefficient of Photo Obseevation factors on some artiffical forest

写真判読資料による林分材積の推定重相関と偏相関 (人工林)

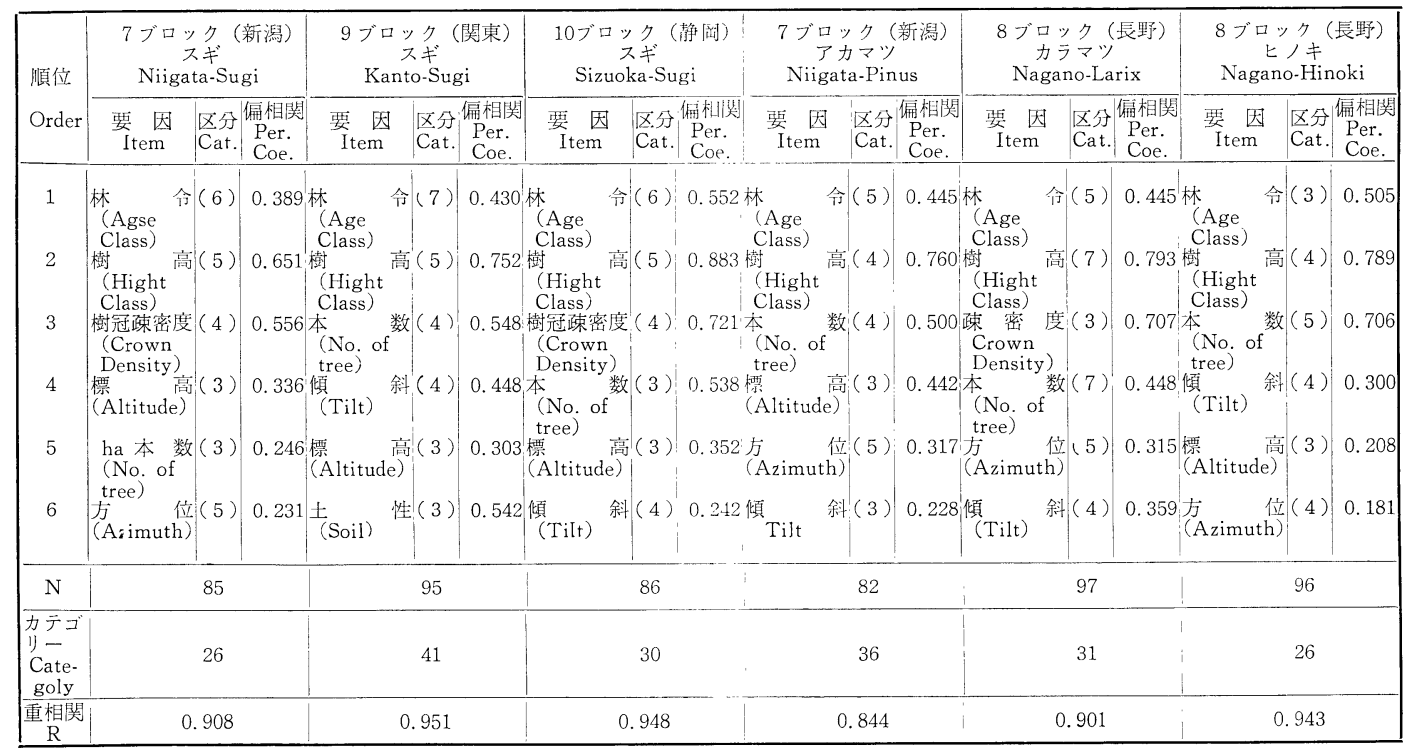


数量で表わされたものであるが，各カテゴリーの表現 には, 写真测定により直接数量として求め5るものも あるが，質的な表現で表わされるものもある。しかし このような場合は両者とも同様な取扱の下に推定目的 に妥当なような巾に類型化され区分されるのであって 数量的な子のでも測定值がそのまま用いられるのでは ない。このことは写真利用を観測にあたっての高度な 技術的要求や測定誤差の险路から解放し平易な活用法 を拡大するものでもめる。

この多変量解析の手法は, 各要因を一度に計算過程 に加えるのではなく, 一つづつ加重しては推定計算を
繰り反してゆくことによって，各要因相互の関連が直 線回帰式の系数表現による内部相関係数として表われ ると同時に夫々の要因の関与性が個々の偏相関係数と して，また夫々の場合の全体推定の精度が重相関係 数, 推定值の標準偏差によって求められる。

Table 2 は要因が調査一時点の材積, 生長量, 枯損 量の推定目的に対してどのような重要さで関与してい るかを上記の偏相関係数の值を参考に上位から順に北 海道帯広営林局管内国有林の二つの森林地带について 示した例である。両者ともにエゾマツ，トドマツを主 材木とする天然林であるがA.（トムラウシ）は全くの

Table 4 Inner Correlation Matrix for Volume Estimation

(トムラウシ) エゾ・トド天然林 Tomuraushi Natural forest

\begin{tabular}{|c|c|c|c|c|c|c|c|c|c|}
\hline \multirow{2}{*}{ Item } & \multicolumn{8}{|c|}{ 単 相 関 Simple Corelation Coefficient } & \multirow{2}{*}{\begin{tabular}{|l}
$\mid$ 単相関 (材積) \\
Y \\
Simple Corr. \\
Coe.
\end{tabular}} \\
\hline & $\mathrm{X}_{1}$ & $\mathrm{X}_{2}$ & $\mathrm{X}_{3}$ & $\mathrm{X}_{4}$ & $\mathrm{X}_{5}$ & $\mathrm{X}_{6}$ & $\mathrm{X}_{7}$ & $\mathrm{X}_{8}$ & \\
\hline $\begin{array}{l}\text { 大径木本数 } \mathrm{X}_{1} \\
\text { No. of Dominant }\end{array}$ & 1.000 & & & & & & & & 0.711 \\
\hline $\begin{array}{l}\text { 局 所地 形 } \mathrm{X}_{2} \\
\text { Land Type }\end{array}$ & 0.042 & 1.000 & & & & & & & 0.268 \\
\hline $\begin{array}{l}\text { 径級混交状況 } \mathrm{X}_{3} \\
\text { Stand Composition }\end{array}$ & 0.145 & -0.087 & 1.000 & & & & & & 0.220 \\
\hline $\begin{array}{l}\text { 樹冠疎密度 } \mathrm{X}_{4} \\
\text { Crown Density }\end{array}$ & 0.452 & 0.052 & 0.009 & 1.000 & & & & & 0.603 \\
\hline 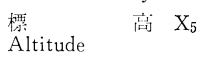 & -0.003 & -0.137 & -0.241 & 0.073 & 1.000 & & & & 0.093 \\
\hline $\begin{array}{l}\text { 位 } \\
\text { Position }\end{array}$ & -0.054 & -0.249 & 0.034 & -0.107 & 0.046 & 1.000 & & & 0.029 \\
\hline $\begin{array}{l}\text { 樹 } \\
\text { Hight Class }\end{array}$ & 0.381 & 0.050 & 0.280 & 0.055 & -0.120 & -0.007 & 1.000 & & 0.467 \\
\hline $\begin{array}{ll}\text { 針広混交割合と } & \mathrm{X}_{8} \\
\text { 㹸呮 } & \\
\text { Mixture Type } & \end{array}$ & 0.323 & 0.139 & 0.110 & 0.133 & -0.062 & 0.018 & 0.377 & 1.000 & 0.463 \\
\hline
\end{tabular}

Table 5 Honbetu Natural Forest

\begin{tabular}{|c|c|c|c|c|c|c|}
\hline & \multicolumn{5}{|c|}{ 要因間の単相関単相関 Simple Correlation Coefficient } & \multirow{2}{*}{$\begin{array}{l}\text { Volume (材積) } \\
\text { Y } \\
\text { Simple Corr. Coe. }\end{array}$} \\
\hline & $\mathrm{X}_{1}$ & $\mathrm{X}_{2}$ & $\mathrm{X}_{3}$ & $\mathrm{X}_{4}$ & $\mathrm{X}_{5}$ & \\
\hline $\begin{array}{l}\text { 樹冠疎密度 }\left(\mathrm{X}_{1}\right) \\
\text { Crown Density }\end{array}$ & 1.000 & & & & & 0.419 \\
\hline $\begin{array}{l}\text { 樹 高 } \\
\text { Hight } \text { Class }\end{array}$ & -0.096 & 1.000 & & & & 0.606 \\
\hline $\begin{array}{l}\text { 大径木本数 }\left(\mathrm{X}_{3}\right) \\
\text { No. of Dominant } \mathrm{T} \text {. }\end{array}$ & 0.235 & 0.436 & 1.000 & & & 0.757 \\
\hline 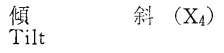 & 0.095 & -0.089 & 0.090 & 1.000 & & 0.106 \\
\hline $\begin{array}{l}\text { 植 生 状 況 }\left(\mathrm{X}_{5}\right) \\
\text { Ground Flor }\end{array}$ & $0.1 \angle 3$ & 0.141 & 0.040 & 0.038 & 1.000 & 0.292 \\
\hline
\end{tabular}

Table 6 Pinus Artifical fosest Niigata

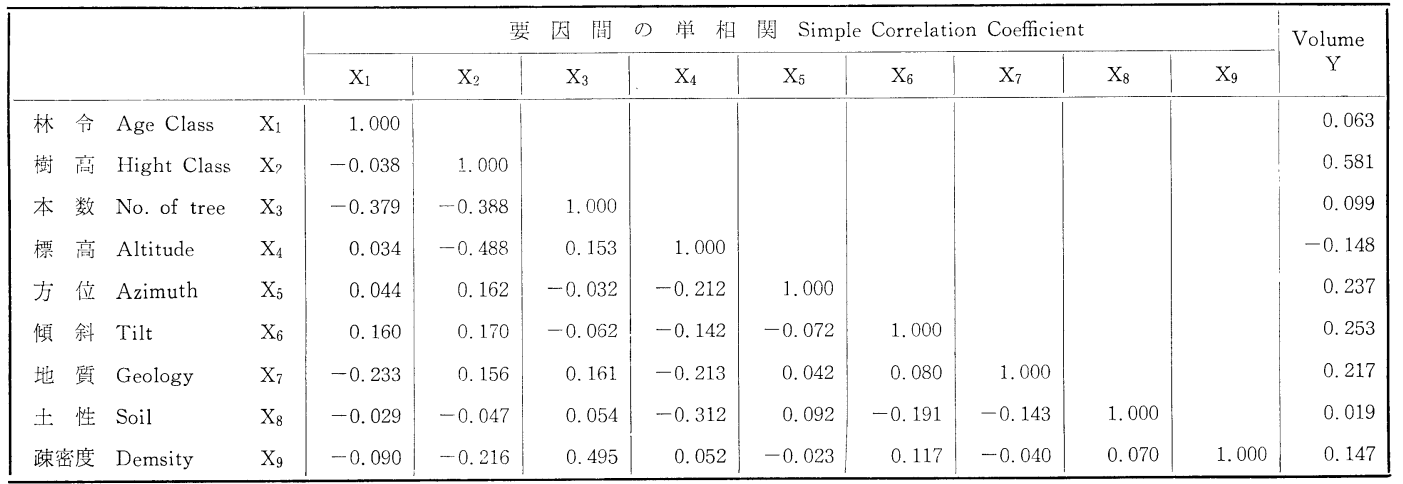


原始林であり，B. (本別) はかつて択伐による人為作 業の加わった林であり, 両者の要因の関与性には全く 異なる様子が見られる。例えば全くの原始林Aは若干 なりと人工の加わった林 Bに比べてすべての調査目的 にはるかに自然環境要因の関与する点が大きく, 材積 推定のためには第一の大径木の本数の多少の次には局 所地形の観察が大切であり, 従来考えら礼ていた樹高 階の重要度ははるか下位となる。一方 B の林では樹高 階は樹冠の踈密度につく大切な観察要因である。これ らの差はそれぞれの森林の成立過程による構造の差に よって特長づけられる特性であり調査に当ってその森 林では何をしらべることが効果的であるか示すもの である。

な扢この解析計算に用いられた要因数は表下列に示 すように多かったが，Table には上位の $5 〜 7$ 位まで の要因を示した。

人工林についての若干の例を Tabie 3. に示す。こ こにおいても樹種, 地域別に要因の重要性が異なるこ とが見られる。

Table 4, 5, 6 は前述の各要因間相互の内部相関係 数を示す例である。Table 4 の原始林では各要因は大 径木本数 $\left(X_{1}\right)$ と樹冠疎密度 $\left(X_{4}\right)$, 樹高階 $\left(X_{7}\right)$ の 間に当然ながら関係が見られる以外はほとんど数值的 に独立である。Table 3 のスギ人工林では林令と樹高 階に著しい関連值 (0.723) があるが Table 4 のアカ マツ林ではその関係はほとんどなく林令はむしろ本数 要因 $(-0.379)$ に関係し, 樹高階は標高階 $(-0.488)$ に 関連する。これはスギ林には見られ枚象である。

\section{4. 推定亡予測点数表の作成}

Estimation and Score table

解析によって求められた要因の関 与性と相互の関連は，それが不偏性 のあるものである限りそれぞれの森 林構成の特性を示するのである。そ れらは推定目的として与えられた外 的基準を最も誤差が少なく予測でき るように各カテゴリーに数量を与光 た場合の結果である，したがってこ の值は外的基準が変った場合に偏相 関值が異なるのは当然であるが，内 部相関の值にも多少の変化があるも のである。またこの計算手法に沶い ては, 同一外的基準に対しても, 計 算に加える要因の順，カテゴリー区 分のちかいによって偏相関係数の值 自体を変化するものである，それは
この多変量解析の手法そのものが，各要因が独立であ ることを仮定しているのに対して，このような森林構 造要因相互，末た環境要因の間には完全な独立性がな いことにもょうう。この内部相関係数，偏相関係は直 線回帰式での回帰係数であるので，相対的な参照数值 としてこれを用いるときに検討に使用する有効性が認 めら礼るものであろう。

したがってこの手法は各要因の独立性や不偏性が推 定計算の結果に影響を扰上济す棌ど仮定に反した場合 はその要因を使う專は不適当である。いいかえれば内 部相関の高い值をもつもの相互については測定の難 易、精度等を参照にいずれか一方をえらぶべきである うし，末た外的基準を異にした場合，著しく他との関 連值を異にする不安定な要因は不偏性について凝問が 生じる。な打同一外的基準に対しても演算に加える要 因の順位を变えた時, 偏相関值が大きく変動するもの についても，棓算上の仮定を満しえないものともい兄 上5。しかし，たとえば一時点での森林の材積の推定 の場合，この目的は写真上からどの上うな要因を測れ ば最もよい推定值がえられるかである。したがってた と充森林の生成の過程や結果環境要因々の従属関係 があるものとしても，写真像に現われる森林観察の要 因としては相互関連が明らかに数值上に認められない 場合はこの両者を要因として用いることは合目的的で 女る。事実上，写真上に記録された森林像の要因は環 境要因との間に数值的に認めうる関連極めて少ない ことが内部相関值によって知られる。それは時間函数 を加えた時はじめて関連が生ずるものである。

写真像を中介とした場合, 森林要因之環境要因はい でれも同等な観察要因として検討されらるものであ る。な打外的基準に対して関与性の少ない要因は測定

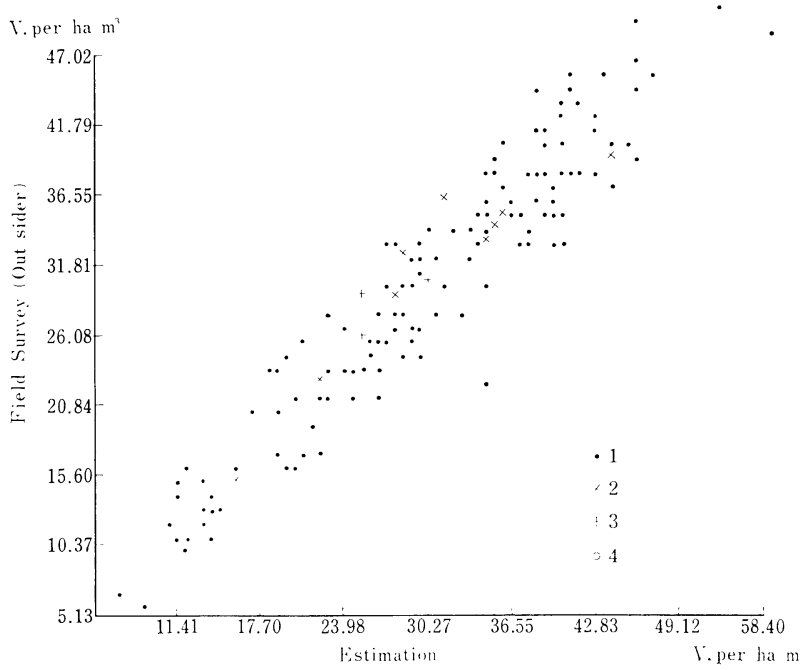

Fig 1 材皘推定 Volume Estimetion (Tomuraushi) 


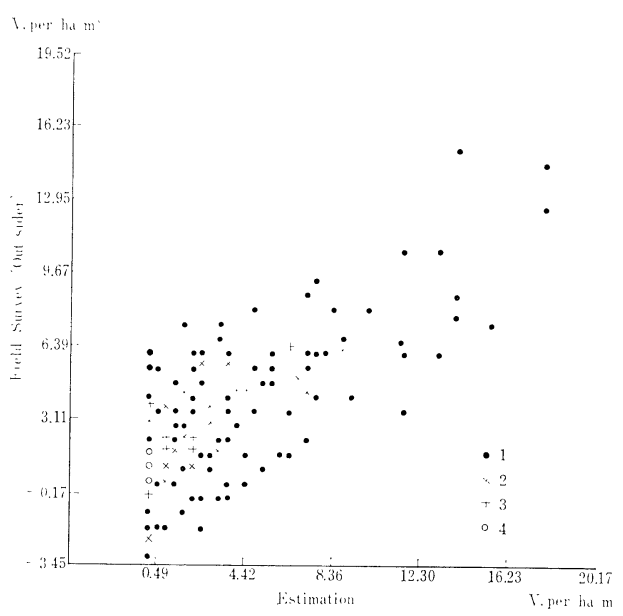

Fig 2 枯損量推定 Inferior Estimation (Tomuraushi)

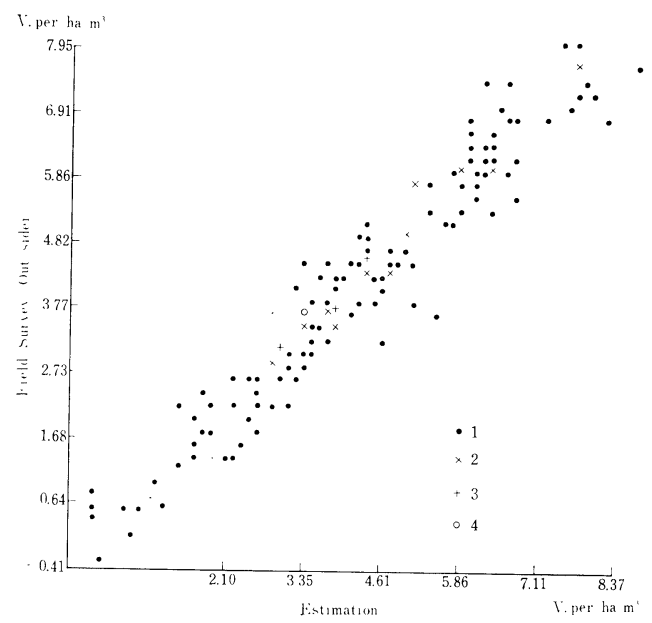

Eig 3 生長量推定 Growth Estimation (Tomurarshi)

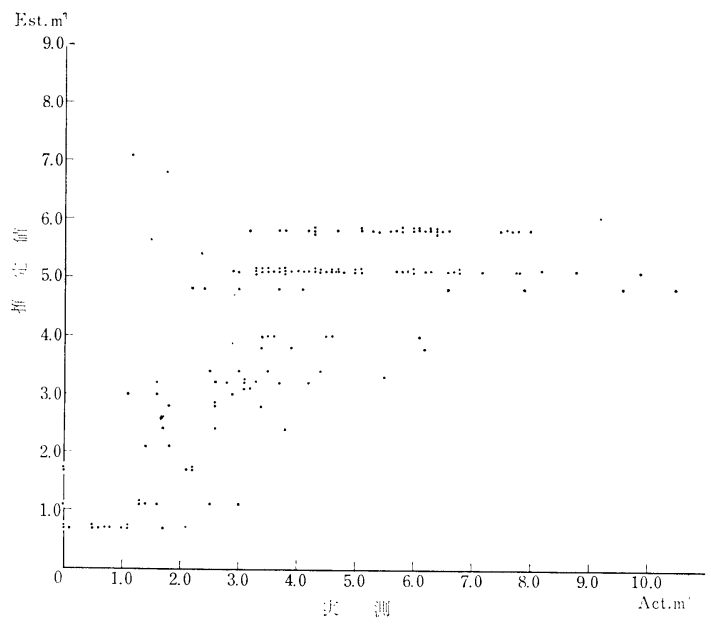

Fig 4 要因数の加重による生長量推定の変化 Voriation of Growth Estimation by Used Items. 要因 Item (2) 大径木本数 針広混交形 mixture Type No, of domimant Tree
の能率と，それを加えることによっ て生ずる効果との検討より取捨選択 されねばならない。

それぞれの推定目的に対して適切 な要因と順序が求められた場合，こ れらによる予測值が電子計算機の演 算によって, 各カテゴリ一毎に最も 適切な点数が与えられ，その集計に よって得られる。

例としてトムラウシ 森林での材 積, 枯損, 生長量, 拈よび人工林新 潟地方スギの材積推定值と実測 值 （外的基準）の比較図を示す。

\section{Fig. 1 Fig. 2 Fig. 3}

推定結果，掞よび Fig. より材積， 生長量については所要の精度が得ら れているが, 枯損量の推定精度が十 分でないのは, Fig. 3 に見られるよ らにこの天然林に打いては少なくと b ha 当り $7 \mathrm{~m}^{3}$ 程度の枯損木は観測 要因に関係なく全面的に過去上り累 積, また自然発生している結果であ り, 推定の対象にならない存在であ ったと思われる。

な招全要因を用いた推定の結果は 前項解析の段階に扮いて既に算出さ れるが，更に要因の選択と順位を改 めることは，この結果の利用を目的 とした点数表作成のための再計算数 值をうるためである。選ばれた要因 とその順のときに最もよい予測值を 光るために各カテゴリーに与えられ た点数（スコア）を要因群の加算順 に表示したものが予測点数表であ る。Table 7。この表は写真により 区分された林型区画，またはクオド ラート区画内の森林の各観察要因, カテゴリーに該当する点数を集計す れば目的とする予測值の得られるも のである。

この際, 用いた要因群が多い程精 度のよくなることは下行の重相関が 增加することで知られるので必要な 精度と観測の能率に上っていくつの 要因までをとるかを定めうる。要因 群偏相関係数は上行の要因を加える ことによって高めうる効果でめり， 
また予測の精度はレンジ，あるいは 分散の值によって知られる。例とし て要因数を増加することによって推 定の精度が高くなる状態を Fig. 4, 5,6 に示す。

このような点数表は, 写真観察の みから, それぞれの森林での現況の 值を個々の林分ごとに推定を可能と するとともに，森林状態が変化した 場合の材型の変化に応ずる数值の予 测を可能とするものである。

おわりにこの報告で述べた処 は, 写真観察によって最も容易に求 め5る因子を用いて多変量解析によ

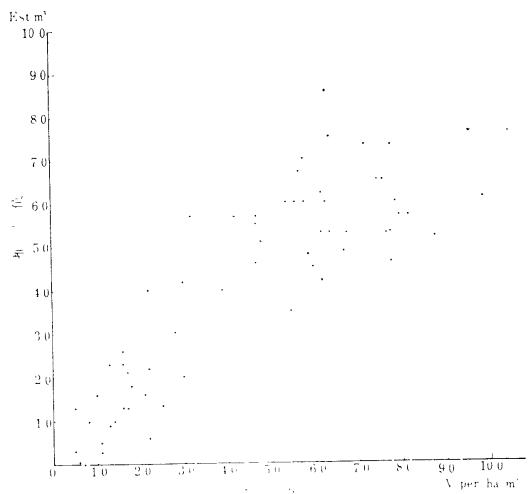

Fig 5 要 因 Item (4)

針広混交形 Mixture Type.

大径木本数 No, of Dominant Tree

径 級 構 成 Stand composition

局所地形 Land Type

Table 7 Score of factors for Volume Estimation Tomuraushi トムラウシ，天然生林，材積推定スコア表

\begin{tabular}{|c|c|c|c|c|c|c|c|c|c|c|c|}
\hline & $\begin{array}{ll}\text { 䐜目要因 } & \text { 覆 } \\
\text { Item of 因 } \\
\text { foctors } & \text { Category }\end{array}$ & $X_{1}$ & $\mathrm{X}_{2}$ & $\mathrm{X}_{3}$ & $X_{t}$ & $X_{5}$ & $\mathrm{X}_{6}$ & $X_{7}$ & $X_{3}$ & $\begin{array}{l}\text { 望相 閔 } \\
\text { Simple } \\
\text { Correlation } \\
\text { Coefficient }\end{array}$ & $\begin{array}{l}\text { 偏闻 } \\
\text { Partial } \\
\text { Correlation } \\
\text { Coefficient }\end{array}$ \\
\hline $\mathrm{X}_{1}$ & $\begin{array}{lll}\text { 大径木 } & 0 \sim 99 \text { 本 (1) } \\
\text { 本 数 } & 100 \sim 200 \text { (2) } \\
& 200\end{array}$ & $\begin{array}{l}179.061 \\
303.288 \\
382.857\end{array}$ & $\begin{array}{l}225.412 \\
348.224 \\
425.413\end{array}$ & $\begin{array}{l}227.821 \\
361.886 \\
434.685\end{array}$ & $\begin{array}{l}210.103 \\
302.618 \\
354.814\end{array}$ & $\begin{array}{l}229.087 \\
325.075 \\
370.920\end{array}$ & $\begin{array}{l}203.260 \\
299.022 \\
339.906\end{array}$ & $\begin{array}{l}194.862 \\
272.428 \\
309.580\end{array}$ & $\begin{array}{l}232.933 \\
300.914 \\
341.917\end{array}$ & 0.711 & 0.563 \\
\hline $\mathrm{X}_{2}$ & 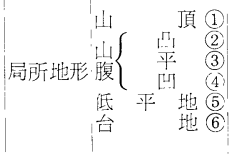 & & $\begin{array}{r}0.000 \\
-\quad 29.435 \\
-\quad 34.762 \\
-\quad 69.425 \\
-113.390 \\
-\quad 32.719\end{array}$ & $\begin{array}{r}0.000 \\
-26.083 \\
-\quad 39.248 \\
-\quad 67.618 \\
-127.070 \\
-\quad 41.989\end{array}$ & $\begin{array}{r}0.000 \\
-\quad 28.034 \\
-\quad 43.747 \\
-\quad 65.327 \\
-106.789 \\
-\quad 31.874\end{array}$ & $\begin{array}{r}0.000 \\
-\quad 30.784 \\
-\quad 48.962 \\
-\quad 62.354 \\
-105.680 \\
-\quad 34.037\end{array}$ & $\begin{array}{r}0.0001 \\
-\quad 44.630 \\
-\quad 65.933 \\
-\quad 74.601 \\
-123.274 \\
-\quad 44.633\end{array}$ & $\begin{array}{r}0.000 \\
-\quad 53.100 \\
-78.410 \\
-\quad 81.943 \\
-136.579 \\
-\quad 53.399\end{array}$ & $\begin{array}{r}5.000 \\
-\quad 01.266 \\
-76.966 \\
-\quad 82.899 \\
-125.665 \\
-\quad 51.517\end{array}$ & 0.268 & 0.492 \\
\hline$X_{3}$ & $\begin{array}{|cccc|} & \text { O. } & \text { O } & (1 \\
\text { 径級構成 } & \text { O. } & \text { B } & \text { (2) } \\
\text { O. } & \text { Y } & (3) \\
& \text { O. B. Y } & (4) \\
\text { B. } & Y & (5)\end{array}$ & & & $\begin{array}{r}0.000 \\
-28.926 \\
-51.807 \\
-\quad 1.268 \\
80.838\end{array}$ & $\begin{array}{r}0.000 \\
-30.402 \\
-79.782 \\
-33.915 \\
4.949\end{array}$ & $\begin{array}{r}0.000 \\
-\quad 30.622 \\
-108.288 \\
-\quad 14.435 \\
3.188\end{array}$ & $\begin{array}{r}0.000 \\
-\quad 30.674 \\
-112.083 \\
-\quad 42.386 \\
-\quad 13.377\end{array}$ & $\begin{array}{r}0.000 \\
-\quad 10.513 \\
-100.905 \\
-\quad 10.037 \\
27.103\end{array}$ & $\begin{array}{r}0.000 \\
-17.173 \\
-92.618 \\
-17.602 \\
11.423\end{array}$ & 0.220 & 0.285 \\
\hline $\mathrm{X}_{4}$ & 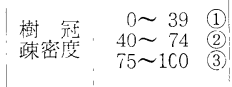 & & & & $\begin{array}{r}0.000 \\
11.719 \\
85.715\end{array}$ & $\begin{array}{r}0.000 \\
18.164 \\
90.604\end{array}$ & $\begin{array}{r}0.000 \\
40.785 \\
113.749\end{array}$ & $\begin{array}{r}0.000 \\
44.571 \\
119.606\end{array}$ & $\begin{array}{r}0.000 \\
43.440 \\
117.369\end{array}$ & 0.603 & 0.602 \\
\hline $\mathrm{X}_{5}$ & 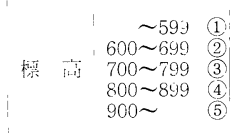 & & & & & $\begin{array}{r}0.000 \\
-37.159 \\
-25.922 \\
-2.468 \\
-47.313\end{array}$ & $\begin{array}{r}0.000 \\
-32.511 \\
-22.722 \\
-0.336 \\
-39.230\end{array}$ & $\begin{array}{r}0.000 \\
-24.203 \\
-38.676 \\
-16.756 \\
-63.190\end{array}$ & $\begin{array}{r}0.000 \\
-30.129 \\
-40.233 \\
-20.177 \\
-62.383\end{array}$ & 0.093 & 0.332 \\
\hline $\mathrm{X}_{6}$ & 位置 年 & & & & & & $\begin{array}{r}0.000 \\
45.928 \\
-0.059 \\
21.261\end{array}$ & $\begin{array}{r}0.000 \\
33.378 \\
-12.938 \\
15.859\end{array}$ & $\begin{array}{r}0.000 \\
29.346 \\
-13.613 \\
13.071\end{array}$ & 0.029 & 0.294 \\
\hline $\mathrm{X}_{7}$ & \begin{tabular}{l|r|} 
& $\sim 18$ \\
樹高 & 19 \\
$22 \sim 21$
\end{tabular} & & & & & & & $\begin{array}{r}0.000 \\
41.736 \\
92.284\end{array}$ & $\begin{array}{r}0.000 \\
20.089 \\
66.096\end{array}$ & 0.467 & 0.364 \\
\hline & 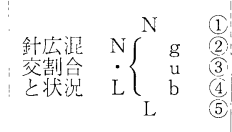 & & & & & & & & $\begin{array}{r}0.000 \\
-\quad 6.927 \\
-23.773 \\
14.023 \\
-41.799\end{array}$ & 0.463 & 0.314 \\
\hline & $\begin{array}{l}\text { 相 関 係 数 } \\
\text { Iultiple Correlation } \\
\text { oefficient }\end{array}$ & 0.771 & 0.760 & 0.783 & 0.834 & 0.849 & 0.862 & 0.884 & 0.894 & & \\
\hline & $\begin{array}{l}\text { 因群偏相関係数 } \\
\text { artial Correlation } \\
\text { oefficient of factors }\end{array}$ & & 0.147 & 0.082 & 0.212 & 0.098 & $0.079^{\prime}$ & 0.151 & 0.677 & & \\
\hline
\end{tabular}


り写真情報利用の効果を高め，また J:

それを利用に向って編集する方法に ついてである, その情報抽出のシス テムは Fig. 7 の如くである。

計算例として示したものは森林の 材積, 生長量, 枯損量であって, そ つ基準資料（外的基準）は一時点で の調査結果であるため, いわば静止 せる森林の断面量である。したがっ て, この結果から, 将来の予测值を 求めるについてはその森林が現況の 各林型に打ける推移をとのまま継続 して行くと仮定することが条件とな る。

文頭において記した如く，森林を 動的にとらえることが本来の目的で めるならば，それは時間的な要素を含めた測定值を基 準としたとき，始めて確実さを持った将来の予測が可 能となるものである。今後これは経年変化の記録を写 真像から求めうることなどで検討が行なわれねばなら ない。
要 因 Item. (8)

針広混交形 Mixture Type.

大径木本数 No. of Dominant Tree.

径級構成 Stand Comqosition

局所地形 Land Type

稚 樹 発生 Regeneration

全 体 数 Total No. of. tree.

標 高 Altitude

方 位 Azimuth
（1）天然林の調查法に関する研究 中島篇他 3 名 林試研報 No.227号, March. 1970 .

（2）数量化による地位指数の推定法 西沢正久他 2 名 林試研報 No.176 March 1965.

3 数量化と予湘に関する根本概念 林知已夫 統計数理研究所率報 7.119 .59 .

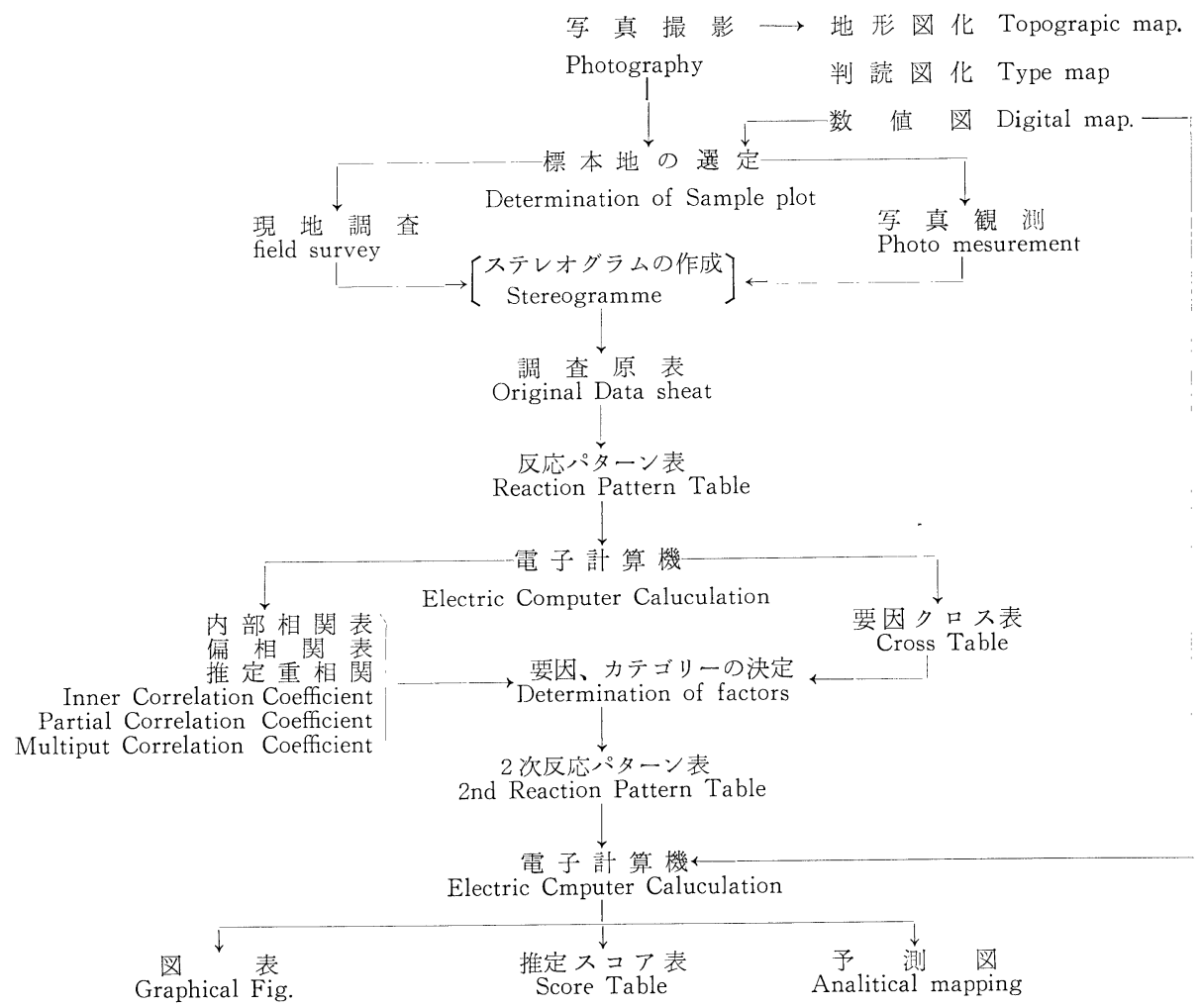

Fig. 7 Draw System of Photo Information for Estimation 空中写真予測抽出システム 